\title{
WAKTU TUNGGU PELAYANAN RESEP RAWAT JALAN DI DEPO FARMASI RSUD GUNUNG JATI KOTA CIREBON TAHUN 2016
}

\section{WAITING TIME SERVICES OUTPATIENT PRESCRIPTION IN DEPOT PHARMACY RSUD GUNUNG JATI CIREBON IN 2016}

\author{
Aida Maftuhah ${ }^{1}$, Rinto Susilo ${ }^{1}$ \\ 1. Akademi Farmasi Muhammadiyah Cirebon \\ Jl. Cideng Indah no. 3 Cirebon \\ Email : aidamaftuhah@gmail.co.id \\ Email : rintosusilo88@yahoo.com
}

\begin{abstract}
ABSTRAK
Pelayanan farmasi termasuk dalam salah satu jenis pelayanan rumah sakit yang minimal wajib disediakan oleh rumah sakit dan tidak dapat dipisahkan dari sistem pelayanan kesehatan rumah sakit yang berorientasi kepada pelayanan pasien. Berdasarkan Keputusan Menteri Kesehatan Republik Indonesia No. 129/Menkes/SK/II/2008 tentang Standar Pelayanan Minimal Rumah Sakit, salah satu indikator SPM (Standar Pelayanan Minimal) untuk pelayanan farmasi rumah sakit adalah waktu tunggu pelayanan obat dengan standar waktu tunggu untuk pelayanan obat jadi maksimal 30 menit dan pelayanan obat racikan maksimal 60 menit. Penelitian yang dilakukan ini bertujuan untuk mengetahui rata-rata waktu tunggu pelayanan resep rawat jalan di depo farmasi RSUD Gunung Jati Kota Cirebon. Dari penelitian didapatkan bahwa rata-rata waktu tunggu pelayanan resep adalah 92,41 menit untuk resep non racikan dan 146,31 menit untuk resep racikan. Rata-rata waktu tunggu pelayanan resep racikan dan non racikan ini tidak memenuhi standar pelayanan minimal rumah sakit sesuai Kepmenkes RI No. 129 tahun 2008.
\end{abstract}

Kata kunci : waktu tunggu, pelayanan resep, depo farmasi rawat jalan, RSUD Gunung Jati Kota Cirebon.

\begin{abstract}
Pharmacy services is kind of hospital service that must be required by hospital and it cannot be separated from health service of hospital system that oriented to patient. According to Ministerof Health Republik Indonesia No. 129/Menkes/SK/II/2008 about Minimum of Standard Service Hospital, the waiting time is one of SPM (Minimum of Standard) indicators for pharmacy service in hospital with the maximum time is 30 minutes for prescription service and 60 minutes only for concoction drugs of the maximum time. The aim of this research is to know the average waiting time service of outpatient prescription in Depot Pharmacy RSUD Gunung Jati Cirebon. Based on the data that the writer got, for prescription service need 92.41 minutes then for concoction drugs service is 146.31 minutes. The average waiting time of prescription services both recipe concoction and non concoction
\end{abstract}


do not fulfill from Minimum of Standard Service hospital that contained in Kepmenkes RI No. 129 in 2008.

Key word : lay time, prescription services, depot pharmacy outpatient, Regional Public Hospital (RSUD) Gunung Jati of Cirebon Municipality

\section{PENDAHULUAN}

Kesehatan merupakan kebutuhan yang paling mendasar bagi setiap manusia. Meningkatnya pengetahuan masyarakat dan taraf hidup masyarakat menjadikan kesadaran masyarakat terhadap pentingnya kualitas kesehatan juga terus meningkat. Hal ini menyebabkan kebutuhan masyarakat akan sarana pelayanan kesehatan juga semakin meningkat. Salah satu dari sarana pelayanan kesehatan yang menjadi rujukan masyarakat adalah rumah sakit. Rumah sakit adalah institusi pelayanan kesehatan yang menyelenggarakan pelayanan kesehatan perorangan secara paripurna yang menyediakan pelayanan rawat inap, rawat jalan, dan gawat darurat (Anonim, 2014).

Pelayanan farmasi termasuk dalam salah satu jenis pelayanan rumah sakit yang minimal wajib disediakan oleh rumah sakit dan tidak dapat dipisahkan dari sistem pelayanan kesehatan rumah sakit yang berorientasi kepada pelayanan pasien. Berdasarkan Keputusan Menteri Kesehatan Republik Indonesia No. 129 tahun 2008 tentang standar pelayanan minimal rumah sakit, pelayanan farmasi merupakan salah satu pelayanan rumah sakit yang minimal wajib disediakan oleh rumah sakit. Untuk mengukur pencapaian standar yang telah ditetapkan diperlukan indikator, suatu alat/tolak ukur yang hasil menunjuk pada ukuran kepatuhan terhadap standar yang telah ditetapkan. Adapun tolak ukur standar pelayanan minimal untuk pelayanan farmasi, indikator dan standar dapat dilihat dalam tabel berikut.

Tabel 1. Indikator dan Standar untuk Pelayanan Farmasi Rumah Sakit

\begin{tabular}{|c|c|c|}
\hline Jenis Pelayanan & Indikator & Standar \\
\hline \multirow[t]{6}{*}{ Farmasi } & 1. Waktu tunggu pelayanan & 1. \\
\hline & a. Obat Jadi & a. $\leq 30$ menit \\
\hline & b. Obat Racikan & b. $\leq 60$ menit \\
\hline & $\begin{array}{l}\text { 2. Tidak adanya kejadian } \\
\text { kesalahan pemberian obat }\end{array}$ & $2.100 \%$ \\
\hline & 3. Kepuasan pelanggan & 3. $\geq 80 \%$ \\
\hline & $\begin{array}{l}\text { 4. Penulisan resep sesuai } \\
\text { formularium }\end{array}$ & 4. $100 \%$ \\
\hline
\end{tabular}

(Sumber : Anonim, 2008)

Waktu tunggu pelayanan resep dibagi menjadi 2 (dua) yaitu waktu tunggu pelayanan resep obat jadi dan waktu tunggu pelayanan resep obat racikan. Waktu tunggu pelayanan resep obat jadi adalah tenggang waktu mulai pasien menyerahkan resep sampai dengan menerima obat jadi. Sedangkan waktu tunggu pelayanan obat racikan adalah tenggang waktu mulai pasien menyerahkan resep sampai dengan menerima obat racikan (Anonim, 2008).

Berdasarkan hasil observasi di RSUD Gunung Jati Kota Cirebon bagian depo farmasi rawat jalan, banyak pasien yang mengeluhkan terhadap lamanya waktu tunggu pelayanan resep. Pengukuran waktu tunggu adalah hal yang harus dilakukan setiap periode sesuai dengan standar pelayanan minimal yang harus terpenuhi. Berdasarkan hal tersebut, perlu dilakukan penelitian tentang "Waktu Tunggu Pelayanan Resep pasien rawat jalan di Depo Farmasi RSUD Gunung Jati Kota Cirebon”. 
Penelitian ini bertujuan untuk mengetahui rata-rata waktu tunggu pelayanan resep pasien rawat jalan di depo farmasi RSUD Gunung Jati Kota Cirebon dan mengetahui waktu tunggu pelayanan resep pasien rawat jalan di depo farmasi RSUD Gunung Jati Kota Cirebon telah memenuhi standar dari Kepmenkes RI No. 129 tahun 2008.

\section{METODE PENELITIAN}

Bahan

Subjek penelitian adalah resep pasien rawat jalan yang dilayani oleh depo farmasi rawat jalan RSUD Gunung Jati pada hari senin-sabtu. Jumlah sampel berjumlah 380 lembar resep.

Data primer dalam penelitian ini berupa rata-rata waktu tunggu pelayanan resep racikan dan non racikan di depo farmasi rawat jalan RSUD Gunung Jati Cirebon. Sedangkan data sekunder dalam penelitian ini adalah Standar Pelayanan Minimal Rumah Sakit Permenkes Republik Indonesia No. 129/Menkes/SK/II/2008, salah satu indikator SPM (Standar Pelayanan Minimal) untuk pelayanan farmasi rumah sakit adalah waktu tunggu pelayanan obat dengan standar waktu tunggu untuk pelayanan obat jadi maksimal 30 menit dan pelayanan obat racikan maksimal 60 menit.

\section{Metode}

Penelitian ini merupakan penelitian observasional dengan pengambilan data secara konkuren yaitu pengambilan data penelitian dijalankan bersamaan dengan pelayanan dilaksanakan.

\section{Jalannya Penelitian}

Teknik pengumpulan data dalam penelitian ini adalah melalui pengamatan langsung/ observasi dengan menggunakan Lembar Pengumpul Data (LPD) yang berisi data nama pasien beserta identitasnya, waktu (pukul) penerimaan resep, pengerjaan resep, penyerahan obat, serta total waktu pelayanan resep (menit).

\section{Analisis Data}

Analisis data menggunakan teknik analisis univariat (analisis deskriptif). Dalam analisis ini umumnya hanya menghasilkan distribusi frekuensi dan persentase jumlah resep racikan dan non racikan, serta rata-rata waktu tunggu pelayanan resep racikan dan non racikan.

Rumus rata-rata (Mean)

$\bar{X}=\sum \mathrm{X} / \mathrm{N}$

Keterangan:

$\bar{X}=$ waktu rata-rata

$\sum X=$ jumlah waktu pelayanan

$\mathrm{N}=$ jumlah sampel

Penilaian kecepatan pelayanan resep ini dikatakan memenuhi persyaratan Keputusan

Menteri Kesehatan Republik Indonesia Nomor 129 tahun 2008 tentang Standar Pelayanan Minimal Rumah Sakit apabila :

1. Untuk resep obat jadi, memenuhi persyaratan apabila kecepatan waktu pelayanan $\leq 30$ menit.

2. Untuk resep obat racikan, memenuhi persyaratan apabila kecepatan waktu pelayanan $\leq$ 60 menit.

\section{HASIL DAN PEMBAHASAN}

Dari hasil penelitian, didapat jumlah sampel dalam penelitian ini sebanyak 390 resep, terdiri dari 289 resep non racikan dan 101 resep racikan persentase resep racikan dan non racikan dapat dilihat pada tabel 3. rata-rata waktu tunggu pelayanan resep yaitu 92,41 menit untuk resep non racikan dan 146,31 menit untuk resep racikan. 
Tabel 2. Jumlah Sampel Berdasarkan Jenis Resep Racikan dan Non Racikan yang dilayani Depo Farmasi Rawat Jalan RSUD Gunung Jati

\begin{tabular}{cccc}
\hline No & Jenis Resep & Jumlah Sampel & Persentasi \\
\hline 1 & Racikan & 101 Resep & $25,9 \%$ \\
2 & Non Racikan & 289 Resep & $74,1 \%$ \\
\hline & Total & 390 Resep & $100 \%$ \\
\hline
\end{tabular}

Tabel 3. Rata-rata Waktu Tunggu Pelayanan Resep di Depo Farmasi Rawat Jalan Lantai 1 RSUD Gunung Jati Kota Cirebon pada Tiap Hari Kerja

\begin{tabular}{|c|c|c|c|c|c|c|c|c|c|}
\hline \multirow[b]{3}{*}{ Hari } & \multirow[b]{3}{*}{ Jenis Resep } & \multicolumn{6}{|c|}{ Resep Diterima Pada Pukul } & \multirow{2}{*}{\multicolumn{2}{|c|}{ Total }} \\
\hline & & \multicolumn{2}{|c|}{$09.00-11.00$} & \multicolumn{2}{|c|}{$11.00-13.00$} & \multicolumn{2}{|c|}{ 13.00-Selesai } & & \\
\hline & & $\begin{array}{c}\text { Jml } \\
\text { Resep }\end{array}$ & $\begin{array}{c}\text { Waktu } \\
\text { Tunggu } \\
\text { (menit) }\end{array}$ & $\begin{array}{l}\text { Jml } \\
\text { Resep }\end{array}$ & $\begin{array}{c}\text { Waktu } \\
\text { Tunggu } \\
\text { (menit) }\end{array}$ & $\begin{array}{c}\text { Jml } \\
\text { Resep }\end{array}$ & $\begin{array}{l}\text { Waktu } \\
\text { Tunggu } \\
\text { (menit) }\end{array}$ & $\begin{array}{c}\text { Jml } \\
\text { Resep }\end{array}$ & $\begin{array}{l}\text { Waktu Tunggu } \\
\text { (menit) }\end{array}$ \\
\hline \multirow[t]{2}{*}{ Senin } & Non Racikan & 18 & 39,72 & 22 & 152,41 & 17 & 142,47 & 57 & $113,86 \pm 61,9$ \\
\hline & Racikan & 5 & 81,2 & 12 & 153,08 & 6 & 178 & 23 & $143,96 \pm 54,69$ \\
\hline \multirow[t]{2}{*}{ Selasa } & Non Racikan & 28 & 46,07 & 21 & 130,81 & 18 & 179,11 & 67 & $108,37 \pm 63,61$ \\
\hline & Racikan & 2 & 47 & 18 & 166,5 & 8 & 221,25 & 28 & $173,61 \pm 61,10$ \\
\hline \multirow[t]{2}{*}{ Rabu } & Non Racikan & 13 & 43,61 & 10 & 116,1 & 9 & 147,11 & 32 & $\mathbf{9 5 , 3 8} \pm \mathbf{5 4 , 5 0}$ \\
\hline & Racikan & - & - & 7 & 131,43 & 3 & 196,67 & 10 & $151,00 \pm 47,47$ \\
\hline \multirow[t]{2}{*}{ Kamis } & Non Racikan & 25 & 42,68 & 20 & 126,05 & 16 & 135,06 & 61 & $94,25 \pm 52,04$ \\
\hline & Racikan & 4 & 69,25 & 14 & 145,64 & 6 & 186,67 & 24 & $143,17 \pm 48,21$ \\
\hline \multirow[t]{2}{*}{ Jumat } & Non Racikan & 19 & 65,42 & 17 & 99,71 & 8 & 89,5 & 44 & $\mathbf{8 3 , 0 5} \pm 37,39$ \\
\hline & Racikan & 9 & 97,56 & 3 & 175,33 & 2 & 86,5 & 14 & $112,64 \pm 44,93$ \\
\hline \multirow[t]{2}{*}{ Sabtu } & Non Racikan & 16 & 19,88 & 10 & 16,1 & 2 & 10,5 & 28 & $17,86 \pm 5,84$ \\
\hline & Racikan & 2 & 41 & - & - & - & - & 2 & $41,00 \pm 9,90$ \\
\hline & & \multirow{2}{*}{\multicolumn{2}{|c|}{ Total }} & & Non $\mathrm{Ra}$ & & & $\underline{289}$ & $\underline{92,41}$ \\
\hline & & & & & Racikan & & & 101 & 146,31 \\
\hline
\end{tabular}

Hasil ini menyatakan bahwa rata-rata waktu tunggu pelayanan resep di depo farmasi rawat jalan RSUD Gunung Jati Kota Cirebon tidak memenuhi standar pelayanan minimal rumah sakit sesuai Kepmenkes No.129 Tahun 2008 yang mempunyai standar pelayanan minimal untuk resep non racikan $\leq 30$ menit dan resep racikan $\leq 60$ menit.

Setiap sampel resep racikan maupun non racikan mempunyai waktu tunggu pelayanan resep yang berbeda-beda. Resep yang memenuhi standar waktu tunggu pelayanan resep adalah sebanyak 63 resep untuk resep non racikan dan 10 resep untuk resep racikan. Resep tersebut merupakan resep yang diterima pada pukul 09.00 - 11.00 WIB dan seluruh resep pada hari sabtu dengan rata-rata waktu tunggu yang memenuhi syarat yaitu 17,86 menit untuk resep non racikan ( $\leq 30$ menit) dan 41 menit untuk resep racikan $(\leq 60$ menit). Hal ini dikarenakan belum terjadinya penumpukan resep pada pukul $09.00-11.00$ WIB dan jumlah resep pada hari sabtu yang lebih sedikit dibandingkan hari lain.

Resep yang diterima diatas pukul 11.00 WIB mempunyai waktu tunggu lebih lama dibandingkan resep yang diterima pada pukul $09.00-11.00 \mathrm{WIB}$, karena mulai pukul 11.00 WIB semua poliklinik sudah lengkap dalam memberikan pelayanannya sehingga di depo farmasi juga terjadi penumpukan resep. 
Jumlah resep yang diterima di depo farmasi juga merupakan salah satu faktor yang mempengaruhi waktu tunggu pelayanan resep. Selain itu, jumlah item obat tiap resep serta jumlah racikan pada tiap resep juga mempengaruhi pada lamanya waktu tunggu pelayanan resep.

Sumber Daya Manusia (SDM) yang kurang memadai, banyak atau sedikitnya tenaga teknis kefarmasian di depo farmasi sangat berpengaruh pada kecepatan pelayanan resep di depo farmasi tersebut. Petugas yang terdiri dari 1 orang apoteker, 6 orang tenaga teknis kefarmasian ( 2 orang pada tahap penerimaan dan input data resep, 4 orang pada tahap pengerjaan resep) dan 1 orang prakarya, kurang memadai dalam pelayanan resep di depo farmasi rawat jalan lantai 1 RSUD Gunung Jati Kota Cirebon. Berdasarkan Permenkes nomor 56 tahun 2014 tentang Klasifikasi dan Perizinan Rumah Sakit, SDM Rumah Sakit Umum kelas B untuk tenaga kefarmasian yang bertugas di rawat jalan paling sedikit terdiri atas 4 (empat) apoteker yang dibantu oleh paling sedikit 8 (delapan) orang tenaga teknis kefarmasian. Sedangkan dalam Permenkes nomor 58 tahun 2014 tentang Standar Pelayanan Kefarmasian di Rumah Sakit, dijelaskan bahwa perhitungan kebutuhan apoteker berdasarkan beban kerja pada pelayanan kefarmasian di rawat jalan yang meliputi pelayanan farmasi manajerial dan farmasi klinik dengan aktivitas pengkajiana resep, penyerahan obat, pencatatan penggunaan obat dan konseling, idealnya dibutuhkan tenaga apoteker dengan rasio 1 apoteker untuk 50 pasien.

Sampel dalam penelitian ini adalah resep dengan nomor antrian. Dalam pelayanan resep di depo farmasi rawat jalan lantai 1 RSUD Gunung Jati Kota Cirebon terdapat beberapa resep yang dikerjakan tanpa nomor antrian, yaitu resep untuk pasien umum. Resep ini langsung dikerjakan setelah dilakukan konfirmasi harga obat sehingga menghambat dalam pengerjaan resep dengan nomor antrian.

Dalam tiap tahap pelaksanaan pelayanan resep, kadang terjadi beberapa masalah yang dapat mempengaruhi lamanya waktu tunggu pelayanan resep. Pada tahap penerimaan dan input data resep, beberapa masalah yang terjadi diantaranya sistem / program komputer yang terbatas sehingga beberapa pekerjaan dilakukan secara manual, data pasien yang tidak lengkap, ketidak sesuaian antara data pasien pada resep dan pada persyaratan pengklaiman, peresepan dokter yang tidak lengkap atau tidak terbaca, jenis obat yang sama dari poliklinik yang berbeda karena pasien berobat pada beberapa poliklinik sehingga harus dikonfirmasi terlebih dahulu pada petugas di poliklinik dan pada dokter yang bersangkutan. Pada tahap pengerjaan resep, beberapa masalah yang terjadi diantaranya persediaan obat yang habis dikarenakan ruangan dan tempat penyimpanan obat yang terbatas sehingga obat harus diambil terlebih dahulu di gudang atau di depo farmasi lain setelah dilakukan konfirmasi melalui telepon. Pada tahap penyerahan obat, beberapa masalah yang terjadi diantaranya tempat penyerahan obat yang sempit karena bergabung dengan kasir dan tempat pengkajian resep dan input data resep, waktu dalam menginformasikan obat yang terbatas dikarenakan hanya ada 1 apoteker dalam penyerahan obat sedangkan pasien lain sudah menunggu.

\section{KESIMPULAN}

Berdasarkan hasil penelitian yang dilakukan di depo farmasi rawat jalan lantai 1 RSUD Gunung Jati Kota Cirebon tentang waktu tunggu pelayanan resep yang didasari oleh Keputusan Menteri Kesehatan Republik Indonesia Nomor 129 Tahun 2014 tentang Standar Pelayanan Minimal Rumah Sakit, dapat disimpulkan yaitu rata-rata waktu tunggu pelayanan resep untuk jenis resep non racikan adalah 92,41 menit dan untuk jenis resep racikan adalah 146,31 menit. Hal ini menunjukkan bahwa rata-rata waktu tunggu pelayanan resep di depo farmasi rawat jalan lantai 1 RSUD Gunung Jati Kota Cirebon tidak memenuhi standar pelayanan minimal waktu tunggu pelayanan resep yaitu untuk resep non racikan $\leq 30$ menit dan untuk resep racikan $\leq 60$ menit. 


\section{DAFTAR PUSTAKA}

Anonim. 2008. Keputusan Menteri Kesehatan Republik Indonesia Nomor 129/MENKES/SK/II/2008 Tentang Standar Pelayanan Minimal Rumah Sakit. Jakarta : Depkes RI.

Anonim. 2009. Undang-Undang Republik Indonesia Nomor 44 Tahun 2009 Tentang Rumah Sakit. Jakarta.

Anonim. 2014. Peraturan Menteri Kesehatan Republik Indonesia Nomor 56 Tahun 2014 Tentang Klasifikasi dan Perizinan Rumah Sakit. Jakarta : Depkes RI.

Anonim. 2014. Peraturan Menteri Kesehatan Republik Indonesia Nomor 58 Tahun 2014 Tentang Standar Pelayanan Kefarmasian Di Rumah Sakit. Jakarta : Depkes RI.

Ayuning, T. P. 2011. Analisis Waktu Tunggu Pelayanan Resep Umum Depo Farmasi Rawat Jalan RS Karya Bhakti Tahun 2011. Tesis. Depok : FKM UI.

Hartono. 2013. Evaluasi Waktu Tunggu Resep di Instalasi Farmasi RSI PKU Muhammadiyah Palangkaraya. Karya Tulis Ilmiah. Palangkaraya : Universitas Muhammadiyah Palangkaraya.

Notoatmodjo, S. 2010. Metodologi Penelitian Kesehatan. Jakarta : Rineka Cipta.

Nova, R. F. 2010. Pengaruh Kualitas Pelayanan Terhadap Kepuasan Pasien Rawat Inap Pada Rumah Sakit PKU Muhammadiyah Surakarta. Skripsi. Surakarta : Universitas Sebelas Maret.

Septini, R. 2012. Analisis Waktu Tunggu Pelayanan Resep Pasien Askes Rawat Jalan Di Yanmasum Farmasi RSPAD Gatot Soebroto Tahun 2011. Tesis. Depok : Universitas Indonesia.

Siregar dan Amalia. 2003. Farmasi Rumah Sakit Teori dan Penerapan. Jakarta : EGC.

Widiasari, E. 2009. Analisa Waktu Pelayanan Resep di Instalasi Farmasi Rawat Jalan RS Tugu Ibu Depok Tahun 2009. Skripsi. Depok : Universitas Indonesia.

Wijaya, H. 2012. Analisis Pelaksanaan Standar Pelayanan Minimal (SPM) Rumah Sakit Bidang Farmasi Di Instalasi Farmasi RS Tugu Ibu Tahun 2012. Tesis. Depok : Universitas Indonesia.

Yulianthy. 2012. Analisis Waktu Tunggu Pelayanan Resep Pasien Umum Di Farmasi Unit Rawat Jalan Selatan Pelayanan Kesehatan Sint Carolus Tahun 2011. Tesis. Depok : Universitas Indonesia. 